\title{
Syn-rift unconformities punctuating the lower-middle Cambrian transition in the Atlas Rift, Morocco
}

\author{
J. Javier Álvaro • Hassan Ezzouhairi • \\ Sébastien Clausen · M. Luisa Ribeiro · Rita Solá
}

Received: 25 June 2014 / Accepted: 15 November 2014

(C) Springer-Verlag Berlin Heidelberg 2014

\begin{abstract}
The Cambrian Tamdroust and Bab n'Ali Volcanic Complexes represent two magmatic episodes developed in the latest Ediacaran-Cambrian Atlas Rift of Morocco. Their rifting pulses were accompanied by accumulation of volcanosedimentary edifices (dominated by effusive lava flows in the former and explosive acidic aprons in the latter) associated with active tilting and uplift. Sealing of their peneplaned horst-and-graben palaeotopographies led to the onset of distinct onlapping geometries and angular discordances capping eroded basements ranging from the Ediacaran Ouarzazate Supergroup to the Cambrian Asrir Formation. Previous interpretations of these discordances as pull-apart or compressive events are revised here and reinterpreted in an extensional (rifting) context associated with active volcanism. The record of erosive unconformities, stratigraphic gaps, condensed beds and onlapping patterns
\end{abstract}

\author{
J. J. Álvaro $(\square)$ \\ Centro de Astrobiología (INTA/CSIC), Ctra. de Torrejón a Ajalvir \\ km 4, 28850 Torrejón de Ardoz, Spain \\ e-mail: alvarobjj@cab.inta-csic.es \\ H. Ezzouhairi \\ Département de Géologie, Université Chouaib Doukkali, \\ 24000 El Jadida, Morocco \\ e-mail: ezzouhairi_hassan@yahoo.fr \\ S. Clausen \\ Département de Géosciences, Université de Lille I, \\ 59655 Villeneuve d'Ascq, France \\ e-mail: Sebastien.Clausen@univ-lille1.fr \\ M. L. Ribeiro · R. Solá \\ Laboratório Nacional de Energia e Geologia (LNEG), \\ Ap 7586-Alfragide, 2610-999 Amadora, Portugal \\ e-mail: luisacarvalhoduarte@gmail.com \\ R. Solá \\ e-mail: rita.sola@lneg.pt
}

across the traditional "lower-middle Cambrian" (or Cambrian Series 2-3) transition of the Atlas Rift must be taken into consideration for global chronostratigraphic correlation based on their trilobite content.

Keywords Tholeiitic volcanism · Uplift · Angular discordance $\cdot$ Palaeorelief $\cdot$ Condensation $\cdot$ Gondwana

\section{Introduction}

Intracratonic rifts and their end products, passive-margin basins, are the expression of geological processes everlastingly shaping Earth's crust. Although sedimentary sequences contained within rift branches record the interplay between tectonics, volcanism and climate (MartinsNeto and Catuneanu 2010), the extent to which magmatism actively promotes extensional tectonics, and their related tilting and uplift processes, is poorly constrained. Normal faults, associated with volcanic centres and subsequent hydrothermal activity, contribute to the total strain budget across the rift and control sedimentary patterns, distribution of volcanic products and ore deposits of (sub)economic interest, and the onset of major stratigraphic discontinuities and angular discordances (Olsen and Morgan 2006; Corti 2012). Depending on the magnitude of uplift pulses, which can reach kilometre-scale elevations (McClay et al. 1998; Daradich et al. 2003), angular discordances may extend geographically from a few kilometres to hundreds of kilometres along rift branches. The latter are characteristic rifting features but, in some "fossil" rifts, such as the late Ediacaran-Cambrian Atlas Rift, they are still interpreted as the result of compressive events (see recent discussions in Álvaro and Clausen 2005; Landing et al. 2006; Landing and Geyer 2007; Álvaro 2014). 